\title{
Electrochemical Deposition of Calcium-Deficient Apatite on Stainless Steel Substrate
}

\author{
Hideki MONMA \\ National Institute for Research in Inorganic Materials, 1-1, Namiki, Tsukuba-shi, Ibaraki \\ 305 \\ カルシウム欠損アパタイトのステンレス基板上への電気化学的析出 \\ 門間英毅 \\ 無機材質研究所, 305 茨城県つくば市並木 1-1
}

[Received January 18, 1993; Accepted March 16, 1993]

\begin{abstract}
The electrochemical deposition of calcium-deficient apatite on a stainless steel substrate was conducted by electrolyzing $0.02-0.21 \mathrm{~mol} / \mathrm{dm}^{3} \mathrm{Ca}\left(\mathrm{H}_{2} \mathrm{PO}_{4}\right)_{2} \cdot \mathrm{H}_{2} \mathrm{O}$ $[\mathrm{MCP}]$ solutions added with and without $\mathrm{NaNO}_{3}$ and $\mathrm{NaF}$ at a cathode current of $6 \mathrm{~mA} / \mathrm{cm}^{2}$ at $20-90^{\circ} \mathrm{C}$. The formation of apatite from $\mathrm{F}^{-}$-free MCP solutions was limited in a dilute MCP concentration region. At relatively high MCP concentrations brushite $\left(\mathrm{CaHPO}_{4}\right.$. $\left.2 \mathrm{H}_{2} \mathrm{O}\right)$ or monetite $\left(\mathrm{CaHPO}_{4}\right)$ was deposited. The addition of $\mathrm{NaNO}_{3}$ and/or $\mathrm{NaF}$ was effective for the formation of apatite. Deposited apatite layers were composed of ellipsoidal grains, needles or very fine granules depending on electrolysis conditions. Apatites deposited from $\mathrm{F}^{-}$-added MCP solutions were calciumdeficient apatites with $\mathrm{Ca} / \mathrm{P}$ molar ratios near 1.50 , and contained $\mathrm{F}^{-}, \mathrm{HPO}_{4}{ }^{2-}$ and $\mathrm{Na}^{+}$ions.
\end{abstract}

Key-words : Electrochemical deposition, Apatite deposition, Calcium-deficient apatite

\section{Introduction}

Hydroxyapatite $\left(\mathrm{Ca}_{10}\left(\mathrm{PO}_{4}\right)_{6}(\mathrm{OH})_{2}\right)$ and related calcium phosphates are of considerable interest because of their biocompatible properties, and calcium phosphate coatings have been extensively studied for the surface biocompatible treatment of bio-inert metallic and ceramic materials. Many coating methods such as plasma-spraying, sputtering, electrophoresis, spark discharge in electrolyte, spontaneous deposition in solution, and dipping- or spraypyrolysis have been employed for the purpose. Recently, Redepenning and McIsaac, ${ }^{1)}$ and Shirkhanzadeh ${ }^{2)}$ reported electrolytic depositions of brushite $\left(\mathrm{CaHPO}_{4} \cdot 2 \mathrm{H}_{2} \mathrm{O}\right)$ and hydroxyapatite, respectively, on prosthetic alloys from acidic calcium phosphate solutions. The apatite deposited had a socalled calcium-deficient composition expressed generally as $\mathrm{Ca}_{10-x}\left(\mathrm{HPO}_{4}\right)_{x}\left(\mathrm{PO}_{4}\right)_{6-x}(\mathrm{OH})_{2-x} \cdot n \mathrm{H}_{2} \mathrm{O}$; $0 \leqq x<1$ (referred to as DAp). Similarly, Ban et al. ${ }^{3)}$ prepared apatite films on Ti from a simulated physiological solution $(\mathrm{pH}=7.2)$. The author also studied on the electrolytic depositions and characteristics of $\mathrm{CaHPO}_{4} \cdot 2 \mathrm{H}_{2} \mathrm{O}$ and $\mathrm{CaHPO}_{4}$, and in addition discussed about the deposition of apatite. ${ }^{4)}$ In this paper, the influences of electrolyte concentration, temperature and additives on the electrolytic depositions of calcium phosphates were investigated focusing on particularly the apatite deposition.

\section{Experimental}

Electrolysis runs were carried out by electrolyzing $0.02-0.21 \mathrm{~mol} / \mathrm{dm}^{3} \mathrm{Ca}\left(\mathrm{H}_{2} \mathrm{PO}_{4}\right)_{2} \cdot \mathrm{H}_{2} \mathrm{O}$ (referred to as MCP) solutions $(50 \mathrm{ml})$ added with and without $\mathrm{NaNO}_{3}(7.0 \mathrm{~g})$ and/or $\mathrm{NaF}(0.05 \mathrm{~g})$ at a constant cathode current of $6 \pm 1 \mathrm{~mA} / \mathrm{cm}^{2}$ at $20-90^{\circ} \mathrm{C}$. Exceptionally, a saturated solution of sparingly water-soluble $\mathrm{CaHPO}_{4} \cdot 2 \mathrm{H}_{2} \mathrm{O}$ was used instead of the MCP solutions. Electrodes used were a $\mathrm{Pt}$ plate with $0.1 \times 35 \times 40 \mathrm{~mm}$ as an anode and a SUS304 stainless steel plate with $0.1 \times$ ca. $15 \times$ ca. $20 \mathrm{~mm}$ as a cathode. The resulting deposits on the cathode were washed in distilled water, dried in air, and analysed with a Philips PW1700 X-ray diffractometer (XRD), Digilab FTS-60 infrared spectroscope equipped with a reflection-absorption accessory for thin films (RAS-IR), Akashi ISI-DS130 scanning electron microscope (SEM) and a Philips PV9900-ECON3 energy dispersive X-ray spectrometer (EDX). Table 1 lists apatite deposition samples prepared for characterization.

\section{Results and discussion}

\subsection{Deposition products}

Figure 1 shows deposition products from MCP solutions with and without $\mathrm{NaNO}_{3}$ and/or $\mathrm{NaF}$ at various temperatures. From the $\mathrm{F}^{-}$-free solutions $\mathrm{CaHPO}_{4} \cdot 2 \mathrm{H}_{2} \mathrm{O}$ and $\mathrm{CaHPO}_{4}$ were deposited at low and high temperatures, respectively. The apatite

Table 1. Preparations of apatite deposition samples.

\begin{tabular}{|c|c|c|c|c|c|}
\hline \multirow{2}{*}{ Sample } & \multicolumn{2}{|c|}{ Electrolyte } & \multicolumn{3}{|c|}{ Electrolysisol } \\
\hline & $\begin{array}{l}\text { Solu- } \\
\text { tiona, }\end{array}$ & Additiveb & $\begin{array}{l}\mathrm{T} \\
\left({ }^{\circ} \mathrm{C}\right)\end{array}$ & $\begin{array}{l}\mathrm{DC} \\
(\mathrm{mA} \\
\left(\mathrm{cm}^{2}\right)\end{array}$ & $\stackrel{t}{t}(\min )$ \\
\hline$\overline{\mathrm{DAp} 1}$ & MCP & $\mathrm{NaNO}_{3}+\mathrm{NaF}$ & 37 & 6 & 30 \\
\hline DAp2 & MCP & $\mathrm{NaNO}_{3}+\mathrm{NaF}$ & 40 & 6 & 80 \\
\hline DAp3 & MCP & $\mathrm{NaNO}_{3}+\mathrm{NaF}$ & 65 & 6 & 10 \\
\hline DAp4 & B & $\mathrm{NaF}$ & 65 & 20 & 30 \\
\hline
\end{tabular}




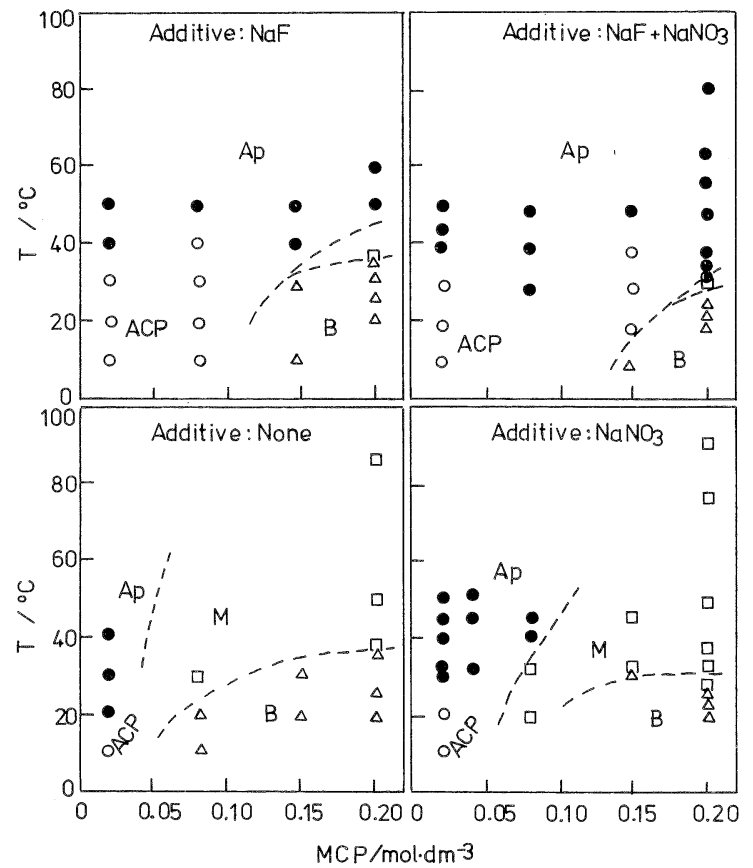

Fig. 1. Deposition products from MCP solutions added with and without $\mathrm{NaNO}_{3}$ and/or $\mathrm{NaF}$ at various $\mathrm{MCP}$ concentrations and temperatures $\left(6 \pm 1 \mathrm{~mA} / \mathrm{cm}^{2}\right)$.

Apatite + probably ACP, $\bigcirc \mathrm{ACP}, \triangle \mathrm{CaHPO}_{4} \cdot 2 \mathrm{H}_{2} \mathrm{O}$,

$\square \mathrm{CaHPO}_{4}$

deposition was observed only at low MCP concentrations. The addition of $\mathrm{NaNO}_{3}$ was effective for the depositions of apatite and amorphous calcium phosphate $\left.\left.\left(\mathrm{Ca}_{3}\left(\mathrm{PO}_{4}\right)_{2} \cdot n \mathrm{H}_{2} \mathrm{O}, 5\right), 6\right) \mathrm{ACP}\right)$. These calcium phosphates are thought to be deposited as a result of $\mathrm{pH}$ increases in the vicinity of the cathode surface. The $\mathrm{pH}$ increases would be induced by probably the reduction $\mathrm{H}_{2} \mathrm{O}+\mathrm{e}^{-} \rightarrow 1 / 2 \mathrm{H}_{2} \uparrow+\mathrm{OH}^{-}$. As $\mathrm{CaHPO}_{4}$. $2 \mathrm{H}_{2} \mathrm{O}$ and $\mathrm{CaHPO}_{4}$ generally precipitate at lower $\mathrm{pH}$ 's than those for apatite and ACP precipitations, no formations of apatite and ACP suggest insufficient $\mathrm{pH}$ increases for their depositions. The use of relatively dilute $\mathrm{MCP}$ concentrations was considered to be effective for increasing $\mathrm{pH}$ near the cathode. A similar effect was obtained also by using high electrolysis currents. ${ }^{4)}$

From the $\mathrm{F}^{-}$-added solutions, the deposition of apatite occurred in wide ranges of the combination of temperature and MCP concentration, accompanying diminutions of the deposition regions of $\mathrm{CaHPO}_{4} \cdot 2 \mathrm{H}_{2} \mathrm{O}$ and particularly $\mathrm{CaHPO}_{4}$. The preferential diminution of $\mathrm{CaHPO}_{4}$ was considered to be related to the ease conversion into apatite of $\mathrm{CaHPO}_{4}$ than $\mathrm{CaHPO}_{4} \cdot 2 \mathrm{H}_{2} \mathrm{O}$ in the presence of $\left.\mathrm{F}^{-} \cdot{ }^{7}\right)$

\subsection{XRD and IR characteristics of apatite deposits}

Typical XRD patterns and the corresponding RAS-IR spectra of apatite deposition layers are shown in Figs. 2 and 3, respectively. The intense diffraction from the (002) or (300) plane suggested

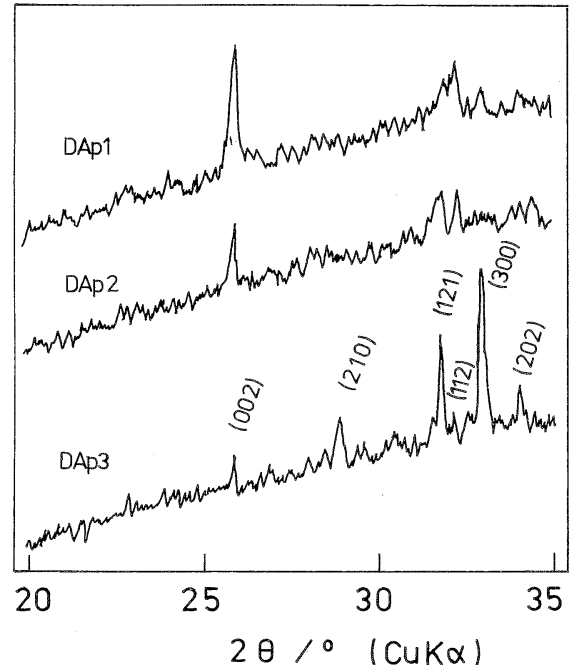

Fig. 2. XRD patterns of apatite deposition layers.

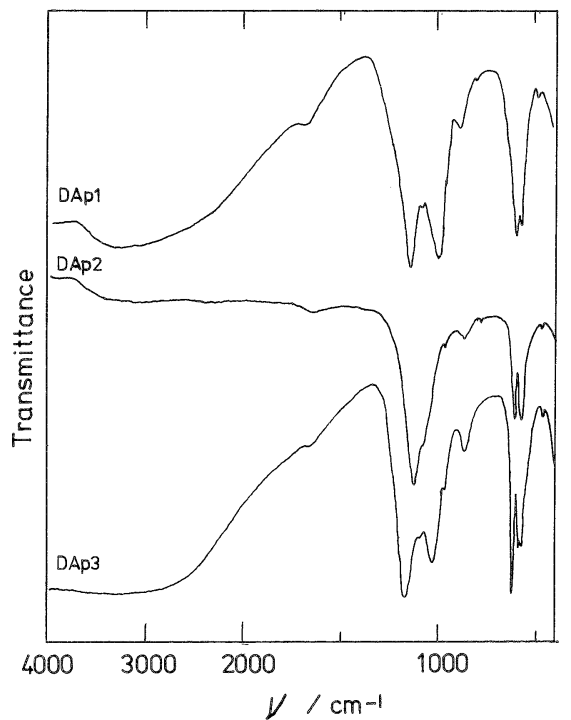

Fig. 3. RAS-IR spectra of apatite deposition layers.

the crystal growth to the [001] direction and oriented depositions of apatite crystals. IR bands at 1100 $1000\left(v_{3}\right), 960\left(v_{1}\right), 600\left(v_{4}\right), 570\left(v_{4}\right)$ and $470 \mathrm{~cm}^{-1}$ $\left(v_{2}\right)$ are assigned to $\mathrm{PO}_{4}$ vibrations in apatite. The band around $870 \mathrm{~cm}^{-1}$ is characteristic of $\mathrm{HPO}_{4}$ and $\mathrm{CO}_{3}$ in apatite, however in this case the band should be due to only $\mathrm{HPO}_{4}$ since no other bands assigned to $\mathrm{CO}_{3}$ in apatite are observed in the range of 1400 to $\left.1550 \mathrm{~cm}^{-1} .8\right)$ The splitted bands 600 and $570 \mathrm{~cm}^{-1}$ are also charateristic of apatite. No bands due to $\mathrm{O}-$ $\mathrm{H}$ (stretch: $3570 \mathrm{~cm}^{-1}$ for $\mathrm{O}-\mathrm{H} \cdots \mathrm{O}-\mathrm{H}$ and 3540 $\mathrm{cm}^{-1}$ for $\mathrm{O}-\mathrm{H} \cdots \mathrm{F}$, libration: $\left.630 \mathrm{~cm}^{-1}\right)^{9), 10)}$ suggested the fluoridation of $\mathrm{OH}$ groups. The $\mathrm{OH}$ sites were presumed to be occupied by $\mathrm{F}^{-}$ions and $\mathrm{H}_{2} \mathrm{O}$ molecules such as $\left(\mathrm{F}, \mathrm{H}_{2} \mathrm{O}\right)_{2}$, from analogy with an expression $\left(\mathrm{OH}, \mathrm{H}_{2} \mathrm{O}\right)_{2}$ for DAp deposited from $\mathrm{F}^{-}$-free MCP solutions.4),11)

\subsection{Morphology of apatite deposits}

Figure 4 shows SEM micrographs of apatite 


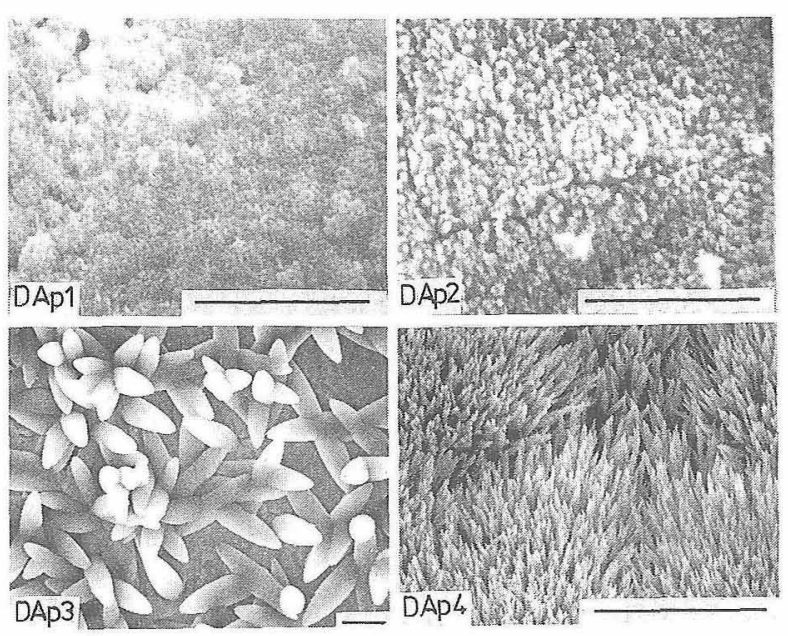

Fig. 4. SEM photographs of apatite deposition layers. Bar : $3 \mu \mathrm{m}$.

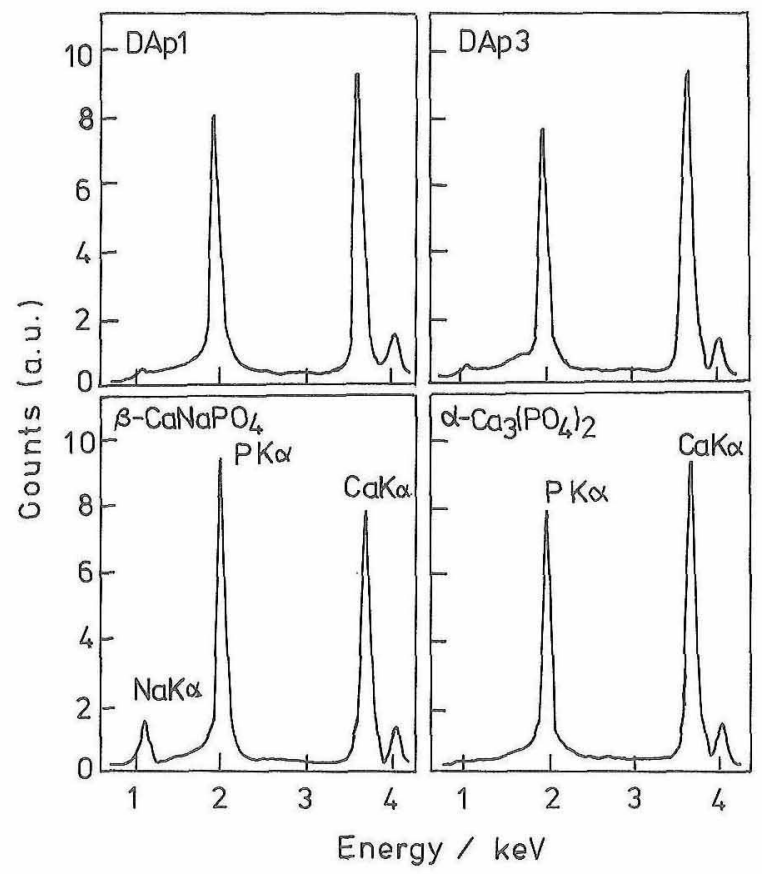

Fig. 5. EDX spectra of DAp deposits and standards.

deposits corresponding to the XRD patterns (Fig. 2). The deposit DAp3, which showed an intense XRD difraction from the (300) plane, was composed of ellipsoidal grains. The deposits DAp1 and DAp2 having intense diffractions from the (002) plane were composed of very fine grains with obscure shapes. The DAp4 is another example having an intense (002) diffraction. In this case, it corresponded to the oriented deposition of apatite needles elongated apparently to the $c$-acix direction. The crystallinity and grain size of the apatite deposits increased with increasing temperature.

3.4 EDX analysis of apatite deposits

Figure 5 shows EDX spectra of DAp samples and standards. The DAp's were estimated to have calcium-deficiencies near to $1.50 \mathrm{in} \mathrm{Ca} / \mathrm{P}$ molar ratio, and contained small amounts of $\mathrm{Na}$. The presence of $\mathrm{Na}$ was reasonable because the substitution of $\mathrm{Na}$ for $\mathrm{Ca}$ is generally observed in apatites precipitated from $\mathrm{Na}^{+}$-containing solutions.

\section{Conclusions}

The electrolytic depositions of calcium phosphates on a stainless steel substrate were carried out by electrolyzing $\quad 0.02-0.21 \mathrm{~mol} / \mathrm{dm}^{3} \quad \mathrm{Ca}\left(\mathrm{H}_{2} \mathrm{PO}_{4}\right)_{2} \cdot \mathrm{H}_{2} \mathrm{O}$ (MCP) solutions added with and without $\mathrm{NaNO}_{3}$ and/or $\mathrm{NaF}$ at a cathode current of $6 \mathrm{~mA} / \mathrm{cm}^{2}$ at 20 $90^{\circ} \mathrm{C}$. The formation of apatite from $\mathrm{F}^{-}$-free $\mathrm{MCP}$ solutions was limited in a region of dilute $\mathrm{MCP}$ concentrations, and at relatively high concentrations brushite $\left(\mathrm{CaHPO} \cdot 2 \mathrm{H}_{2} \mathrm{O}\right)$ or monetite $\left(\mathrm{CaHPO}_{4}\right)$ was deposited. The addition of $\mathrm{NaNO}_{3}$ and/or $\mathrm{NaF}$ was effective for the formation of apatite, and enlarged remarkably the formation region. Apatite deposits were composed of ellipsoidal grains, needles or fine granules depending on temperature and current. Apatite deposited from $\mathrm{F}^{-}$-containing solutions were fluoridated calcium-deficient apatites having a composition like $(\mathrm{Ca}, \mathrm{Na})_{9}\left(\mathrm{HPO}_{4}\right)\left(\mathrm{PO}_{4}\right)_{5}(\mathrm{~F}$, $\left.\mathrm{H}_{2} \mathrm{O}\right)_{2} \cdot n \mathrm{H}_{2} \mathrm{O}$ with $\mathrm{Ca} / \mathrm{P}$ molar ratios near 1.50 .

\section{References}

1) J. Redepenning and J. P. McIsaac, Chem. Mater., 2, 625-27 (1990).

2) M. Shirkhanzadeh, J. Mater. Sci. Lett., 10, 1415-17 (1991).

3) S. Ban, J. Hayashizaki, K. Watanabe, A. Takada and J. Hasegawa, J. J. Dent. Mater., 11 (Spec. Issue 20), 190-91 (1992).

4) H. Monma, Phosphorus Res. Bull., 2, 21-26 (1992).

5) E. D. Eanes, Calcif. Tiss, Res., 5, 133-45 (1970).

6) J. D. Termine and E. D. Eanes, Calcif. Tiss. Res., 10, 17197 (1972).

7) H. Monma and S. Ueno, Gypsum \& Lime, No. 172, 11-17 (1981).

8) G. Bonel and G. Montel, C. A. Acad. Sci. Paris, 258, 923-26 (1964).

9) R. A. Young, W. van der Lugt and J. C. Elliott, Nature, 223, 729-30 (1969).

10) B. Menzel and C. H. Amberg, J. Colloid Interface Sci., 38, 256-64 (1972).

11) S. J. Joris and C. H. Amberg, J. Phys. Chem., 75, 3172-78 (1971). 